\title{
Lékařské vědy
}

UDC 616.28-008.14-072.7-057.1

DOI: $10.24045 /$ pp.2017.4.10

\section{THE HEARING IMPAIRMENT GENDER ASPECTS}

L.V. Snegireva
Candidate of Biological Sciences, assistant professor, ORCID 0000-0002-8935-0511, e-mail:sneglv1@gmail.com, Kursk State Medical University,

Kursk, Russia

\begin{abstract}
The article analyzes the gender features of working age persons (young adults) hearing loss. The audiometry procedure results of young adults at the age from 17 to 28 years old are used as the object of current study. It is revealed that more than $30 \%$ of examinees suffer from hearing impairments of varying severity. Moreover, both among men and women, hearing impairment is detected more often in both auditory analyzers. Less frequently, hearing loss was observed in the left ear of examinees, and the least number of disorders was found in the right ear. However, females are more likely than men to malfunction in each hearing analyzer separately. Among men more often than among women, there is suffer from hearing impairment in both of the auditory analyzer simultaneously.
\end{abstract}

Keywords: audiometry; threshold of hearing acuity; gender factor; working age; hearing loss.

The hearing loss problem is the great point of modern scientific research [2]. A person who is not able to hear as well as someone with normal hearing - hearing thresholds of $25 \mathrm{~dB}$ or better in both ears - is said to have hearing loss. Hearing loss may be mild, moderate, severe, or profound. It can affect one ear or both ears, and leads to difficulty in hearing conversational speech or loud sounds. 'Hard of hearing' refers to people with hearing loss ranging from mild to severe. People who are hard of hearing usually communicate through spoken language and can benefit from hearing aids, cochlear implants, and other assistive devices as well as captioning. People with more significant hearing losses may benefit from cochlear implants. 'Deaf' people mostly have profound hearing loss, which implies very little or no hearing. They often use sign language for communication $[5 ; 6]$. Hearing loss may be mild, moderate, severe, or profound $[1 ; 4]$.
The hearing loss can be classified in the different ways. For example, international classification and Preobrazhensky' classification are widely used. However, the harmonized classification is considered as optimal [3] by the Ministry of Health (Letter of RF from November 6, 2012 No. 14-1 / 10 / 23508 "On the direction of guidelines "Diagnosis, examination of work capacity and prevention of professional sensor neural hearing loss".

Our research purpose was defined as the study the gender features of working age persons (young adults) hearing loss.

The audiometry procedure results were used as the object of the study. The Threshold of hearing was measured for young adults at the age from 17 to 28 years.

The research tasks are:

- to study hearing ability of adults (age up to 28 years);

- to analyze hearing impairment according to the harmonized

Paradigmata poznání. 4. 2017 
classification;

- to identify gender-specific features of adults hearing loss.

Materials and methods.

The hearing ability testing results of 131 adults at the age of 17 to 28 years old were used as the material of our research. $49 \%$ of examinees were represented by males, and 51 $\%$ - by females. The average female age was 20.4 years, and the average age of males was 20.5 years. All participants of the experiment were involved in audiometric tests in the first half of the day. The audiometer AP-02 was used in the study. The research was conduct- ed at the Department of Physics, Informatics and Mathematics of Kursk State Medical University.

Results.

According to the test results, 38,2\% of the young adults up to 28 years, (50 persons) have hearing loss problem. 43 persons, that is $86 \%$ of the examinees with hearing impairment got mild hearing loss. $6 \%$ (3 persons) got a moderate degree of the auditory analyzer disturbance, $2 \%$ (1 person) marked a moderately-severe hearing loss, and another $6 \%$ (two persons) - a severe hearing loss (Figure 1). 


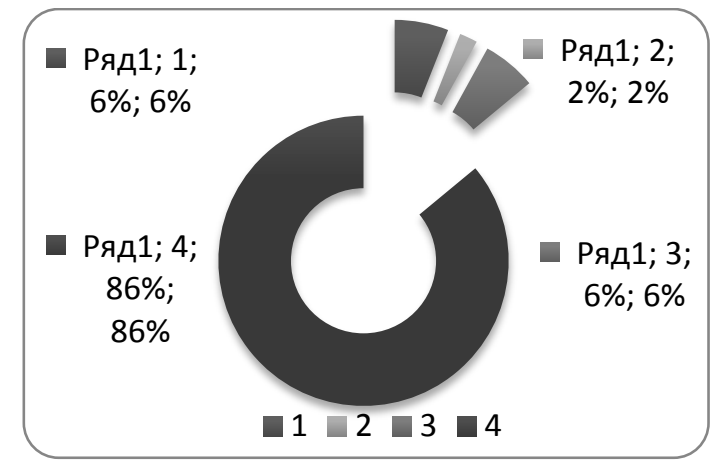

Fig. 1. Hearing impairment in young adults (at the age of 17 to 28 years old).

Note: 1 - severe hearing loss $(6 \%$ of examinees); 2 - moderately-severe hearing loss ( $2 \%$ of examinees); 3 - moderate $(6 \%$ of examinees); 4 - mild hearing loss (86\% of examinees).

At the next stage of our research, the hearing loss gender aspects were esteemed. The research results showed that $54 \%$ of examined males (27 persons) got hearing impairment. The testing of females' hearing ability determined the hearing loss in $46 \%$ of examinees ( 23 persons).

Mild hearing loss was found in $89 \%$ of males, moderate - in $4 \%$ and severe - in $7 \%$ of men- examinees. For females: about tenth part of the women-examinees had severe degree of hearing loss, another $9 \%$ suffered from moderate hearing impairment. $82 \%$ of females has been found to have mild hearing loss. Thus, the testing results shows, that males are more likely to suffer from hearing impairment. However, the females usually get more significant hearing losses.

Studying the localization of hearing loss, we determined the right ear hearing impairment in $5 \%$ of cases. The left ear hearing loss was found in $30 \%$ of audiometry tests. And $60 \%$ of the examinees got abnormal hearing ability in both ears.

According to the gender analysis, more frequently (in $67 \%$ of cases) men are prone to hearing loss in both auditory receptors. Each fourth of men $(26 \%)$ has hearing disorders in the left ear. Only $7 \%$ of males examinees got hearing impairment in right auditory receptor (Figure 2). 


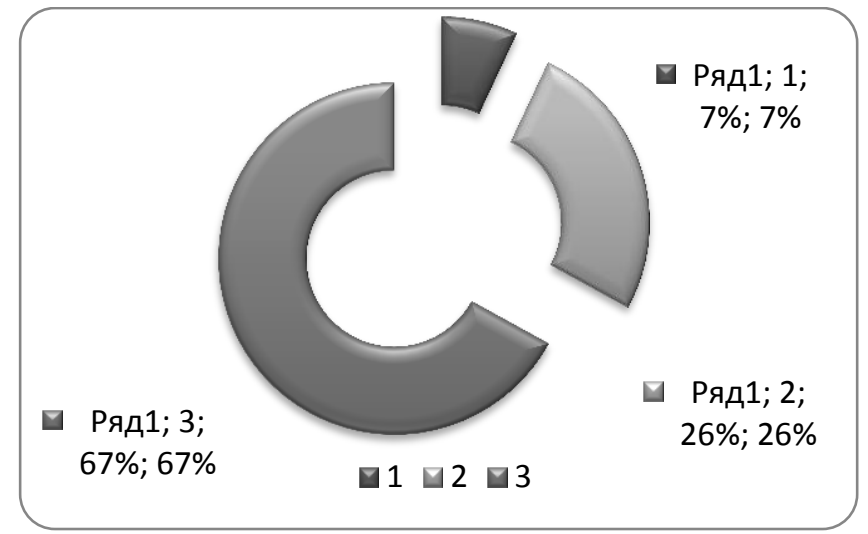

Fig.2. Hearing impairment in male examinees

Note: 1 - right ear hearing impairment ( 7 $\%$ of examinees); 2 left ear hearing loss (26 $\%$ of examinees); 3 - hearing loss in both auditory receptors (67\% of examinees).

Women's hearing impairment had a similar tendency, however, with their own specific features. The vast majority of women with hearing loss $(52 \%)$ had disorder for both ears. It was $15 \%$ less than the number of males with the impairment in both auditory analyzers. The left ear hearing loss was found in $35 \%$ women-examinees that was quarter more than men, suffering from the same impairment. Finally, disorder of the right auditory analyzer was determined in $13 \%$ of females, that is actually twice as men' results (Figure 3).

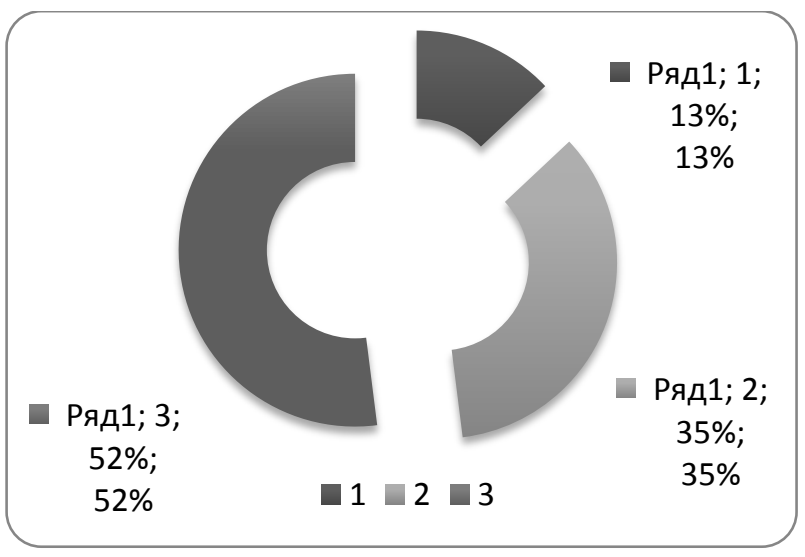

Fig.3. Hearing impairment in female examinees

Note: 1 - right ear hearing impairment (13\% of examinees); 2 - left ear hearing loss (35\% of examinees); 3 - hearing loss in both auditory receptors (52\% of examinees).

Paradigmata poznání. 4. 2017
Thus, both in men and women, hearing impairment was detected more often in both auditory analyzers. Less frequently hearing loss was observed in the left ear of examinees, and the least number of disorders was
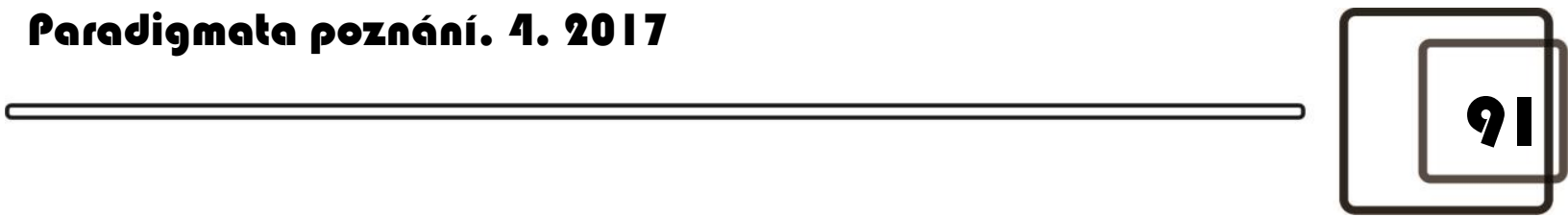
found in the right ear. However, females are more likely than men to malfunction in each hearing analyzer separately. And men more often than women, suffer from hearing impairment in both of the auditory analyzer simultaneously. All the data above allow us to conclude that there are gender-specific features in the hearing loss process.

\section{Bibliography}

1. Берест А. Ю., Красненко А. С. Влияние Регулярного использования аудиоплееров с наушниками на слуховую функцию лиц молодого возраста// Российская оториноларингология. 2013. - № 1 (62). -С. 32-35.

2. Вартанян И. А. Звук - слух - мозг. - Л. : Наука, 1981. - 176 с.

3. ГАРАНТ.PУ: http://www.garant.ru/products/ipo/ prime/doc/70169664/\#ixzz4R9OfQWml (дата обращения: 11.09.2016).

4. Загорянская М. Е., Румянцева М. Г., Дайняк Л. Б. Возможности профилактики развития тугоухости и глухоты на основе системного анализа данных эпидемиологии нарушения слуха // 7 съезд оторинолар. Росии: тез. докл. СПб., 2006. - С. 25-26.

5. Сайт Всемирной организации здравоохранения.

http://www.who.int/mediacentre/factsheets/fs300/ $\mathrm{ru} /$ (дата обращения: 18.10.2016).

6. Терютин Ф. М., Барашков Н. А., Федотова Э. Е. Аудиологический анализ состояния слуха в случайной выборке лиц молодого возраста // Российская оториноларингология. -2012 . - № 4 (59). - C. 101-110.

\section{Bibliography}

1. Berest A. Ju., Krasnenko A. S. Vlijanie Reguljarnogo ispol'zovanija audiopleerov s naushnikami na sluhovuju funkciju lic molodogo vozrasta// Rossijskaja otorinolaringologija. - 2013. - № 1 (62). -S. 32-35.

2. Vartanjan I. A. Zvuk - sluh - mozg. - L. : Nauka, 1981. - $176 \mathrm{~s}$.

3. GARANT.RU:

http://www.garant.ru/products/ipo/prime/doc/701 69664/\#ixzz4R9OfQWml (data obrashhenija: 11.09.2016).

4. Zagorjanskaja M. E., Rumjanceva M. G., Dajnjak L. B. Vozmozhnosti profilaktiki razvitija tugouhosti i gluhoty na osnove sistemnogo analiza dannyh jepidemiologii narushenija sluha // 7 s\#ezd otorinolar. Rosii: tez. dokl. - SPb., 2006. S. 25-26.

5. Sajt Vsemirnoj organizacii zdravoohranenija. .http://www.who.int/mediacentre/factsheets/fs300 /ru/ (data obrashhenija: 18.10.2016).

6. Terjutin F. M., Barashkov N. A., Fedotova Je. E. Audiologicheskij analiz sostojanija sluha v sluchajnoj vyborke lic molodogo vozrasta // Rossijskaja otorinolaringologija. - 2012. - № 4 (59). - C. 101-110.

(C) Snegireva L. V., 2017. 